\title{
CAPACITY TO REDUCE TOTAL DISSOLVED SOLIDS (TDS) LEVELS IN THE IMPLEMENTATION OF ERGONOMIC WATER KNOCK FILTERS
}

\author{
GempurSantoso $^{1}$, YosoWiyarno ${ }^{2}$, Poniman $^{3}$ \\ ${ }^{1,2}$ Industrial Engineering Department, Faculty of Industrial Technology \\ University of PGRI AdiBuana Surabaya \\ ${ }^{3}$ Industrial Engineering Department, Faculty of Industrial Technology \\ University of Muhammadiyah Surabaya \\ E-mail: gempursantoso@unipasby.ac.id
}

\begin{abstract}
Clean water is very important for life. Provision of clean water is still a problem in Indonesia. $80 \%$ of Indonesia's population still consumes water that is not in accordance with health standards. Whether ergonomic water filters knock down for clean water supply is the consumer's interest in water users. This ergonomic knock down water filter all parts are easily removed, carried easily, then reassembled where the location requires water as long as there are waterways to get clean water. The design of this study is comparative and experimental descriptive. Large sample of 30 people who use water filters. Place of Research in the Industrial Engineering Ergonomics Laboratory, PGRI AdiBuana University Surabaya, Indonesia. Data is taken by observation, questionnaire, and experimental results. Data were analyzed using descriptive percentages. The results showed that $73.3 \%$ water filter material chose stainless steel. Ergonomic knock down water filters have the ability to reduce levels of total dissolved solids (TDS) from $380 \mathrm{ppm}$ to 156 ppm, down 224 ppm (41\%). Conclusions: 1) water filter users have the highest interest in choosing filters made of stainless steel, are easily installed and used ergonomically, and anti-oxidation does not cause corrosion; 2) the water yield from ergonomic knock down water fliter is $41 \%$ clearer than before filtering. Suggestion: To implement the Quality Function Deployment of a knock down water filter, ergonomics are expected to be guided by analytical analysis according to the conclusions above.
\end{abstract}

Keywords: Water filter, ergonomics, knock down, total dissolved solids.

\section{INTRODUCTION}

Water is a chemical compound $\mathrm{H} 2 \mathrm{O}$ which is very important for human life and other living things. The function of water for life cannot be replaced by other compounds. Almost all activities carried out by humans need water. For bathing, cleaning the floor, cooking, drinking, washing dishes, washing clothes and others need water. Of course the water needed is clean water. The results of research from the World Bank's water and sanitation consultant (Utamawaterfilter, 20142018) stated that until 2017, there were around 100 million people in Indonesia, with around $80 \%$ still consuming water that was not in accordance with health standards. Clean water supply aside from sources, procurement also requires tools. Ergonomic filters knok down the water purifier as an alternative water purifier needs to be developed. This is so that there will be no difficulty in obtaining and procuring clean water.

Government Regulation No.20 of 1990 classifies water quality into several categories according to their designation. The classification of water according to its designation is as follows.

1. Group A, which is water that can be used as drinking water directly, without prior treatment.

2. Group B, which is water that can be used as raw water for drinking water.

3. Group C, which is water that can be used for fisheries and animal husbandry purposes.

4. Group D, i.e. water that can be used for agriculture, urban business, industrial, and hydroelectric power. (Effendi H, 2003).

Water needs in life are mostly obtained from groundwater and river sources. Surface water is found in lakes, rivers and other water sources. While ground water (ground water), is found in the soil. 
Groundwater can dissolve the parent material minerals from the soil it passes through. Most of the microorganisms that were originally present in ground water are gradually filtered out as water seeps in the soil. The water used by humans is fresh surface water and pure ground water (Rukaesih quoted by Nicola, 2015). Ground water is water that is below the surface of the land. The main characteristics that distinguish groundwater and surface water are the very slow movement of groundwater and very long residence time, which can reach tens or even hundreds of years (Effen in Nicola, 2015).

Mackereth in Nicola, (2015). Conductivity is expressed in units of $\mu$ mhos / $\mathrm{cm}$ or $\mu$ Siemens $/ \mathrm{cm}$. The value of electric conductivity (DHL) is closely related to the value of total dissolved solids (TDS). TDS is usually caused by inorganic materials in the form of ions which are commonly found in waters. TDS consists of mud, fine sand and microorganisms, which are mainly caused by soil erosion or soil erosion carried into water bodies. To reduce levels of TDS in pelu water, filtering / purification is carried out. One of them is with a simple water purifier or ergonomic knock down water purifier.Based on the initial observations of the TDS content when taking the initial data that is the TDS content above that is required. Therefore it is necessary to make a water purifier to reduce TDS levels. In this case, an ergonomic knock down filter model for water purification is made. This purifier can be installed in the bathroom or in the kitchen sink. This ergonomic water purifier is installed without damaging the installation of the installed water pipe. It is expected to save costs in terms of installation and in terms of the product.

According to Wignjosoebroto (1995) in Rahayu (2015) Ergonomics is a scientific discipline that studies humans in relation to their work. Ergonomics plays a role in product design and product innovation, both product development and the creation of new products. In making product designs it should refer to ergonomic principles. Ergonomics standards are the standards required for ergonomics design. Ergonomics standards include: anthropometric dimensions standards, physical environment, work climate, noise, and others (GempurSantoso, 2004). According to Diane (2014) states that one of the principles of ergonomics is to make sure all objects that are easy to use.

In the development of a product or tool by taking into account the level of interest of consumers whether the needs of water purifiers are needed by the public in terms of the broad is the consumer. Ergonomics-based product development really determines whether the product is made ergonomically, this assessment depends on consumers as users, and the ability of water filters in purifying water. Therefore, how is the water filter ergonomic knock down design implemented?; and how much capacity to reduce the level of total dissolved solids (TDS) of an ergonomic knock down water filter?

\section{RESEARCH METHODS}

\section{Data Collection Stage}

The primary data collection was obtained by conducting a survey of the location of sampling well water to determine the level of TDS by measurement, and the distribution of questionnaires to users / consumers who will be carried out design development with 30 respondents. Secondary data were obtained from literature studies.

\section{Data Processing and Analysis Stage}

Data analysis in this study uses comparative descriptive and Quality Function Deployment (QFD), then designed and tested. QFD is used to obtain design models and designs that are ergonomic and in accordance with consumer demand. QFD is described by a matrix called "House of Quality" (HOQ) as in Figure 2 below. 


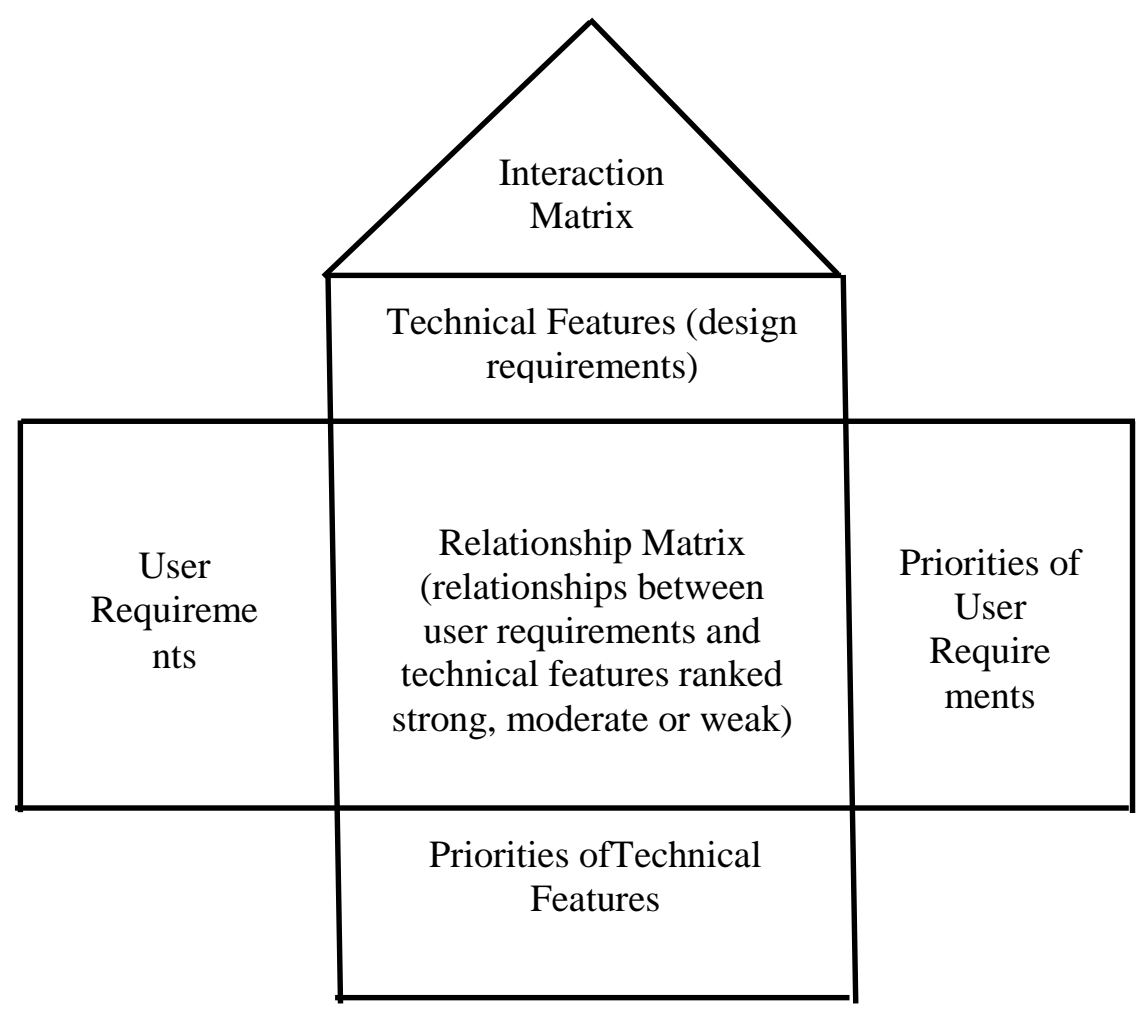

Figure 1. House of Quality Matrix (Demirbilek and Demirkan, 2004)

\section{RESULT AND DISCUSSION}

\section{Implementation of Ergonomic Filter Design}

In determining the Quality Function Deployment based on consumer voices the results are as follows:
Technical requirment is the translation of consumer needs into technical languages. Technical requirements are obtained from interviews, document searches and group discussions with researchers who have the capability in terms of product design. Then get the Technical requirment information as follows (table 1).

\section{a. Technical Requirements Attributes}

Tab1e 1. Technical tabe of water filter requirment

\begin{tabular}{ll}
\hline No & Technical Requirements \\
\hline 1 & Knock down filter model \\
2 & Tube design filter design \\
3 & Portable filter \\
4 & Size $30 \times 16 \mathrm{~cm}$ \\
5 & Material sus $316 /$ stainless \\
6 & Does not change the installed water installation \\
7 & There is a knockdown filter bag \\
8 & There are instructions for use \\
\hline
\end{tabular}


b. Calculation of Raw Weight and Normalization Row Weight

Raw weight value can be used as a basis for determining product attributes that must be developed because the components contained in it are quite comprehensive. The higher the value, the attribute gets more priority, the results see table 2 below.

Table 2. Value of Weight and Normalized Row Weight

\begin{tabular}{llccccc}
\hline No & \multicolumn{1}{c}{ Attribute of importance } & Level of importance & Improvement ratio & $\begin{array}{c}\text { Sales } \\
\text { point }\end{array}$ & Weight & $\begin{array}{c}\text { Normalization weight } \\
\%\end{array}$ \\
\hline 1 & Attractive design & 3.84 & 1.20 & 1.5 & 6.89 & $16 \%$ \\
2 & Material not easily corrosive / stainless & 4.23 & 1.49 & 1.5 & 9.45 & $22 \%$ \\
3 & Material does not break easily & 3.32 & 1.29 & 1.5 & 6.43 & $15 \%$ \\
4 & Resistant to rust & 3.42 & 1.35 & 1.5 & 6.91 & $16 \%$ \\
5 & Products are easy to carry / simple & 3.92 & 1.15 & 1 & 4.49 & $11 \%$ \\
6 & Low prices & 2.58 & 1.10 & 1 & 2.84 & $7 \%$ \\
7 & Easy installation & 3.21 & 1.37 & 1.2 & 5.28 & $12 \%$ \\
\hline
\end{tabular}

Based on the weights in table 2 above show that the attribute of the importance level that has the highest weight value is the material is not easily corrosive. The complete picture of House of Quality (HoQ) is as follows.

\section{House of Quality}

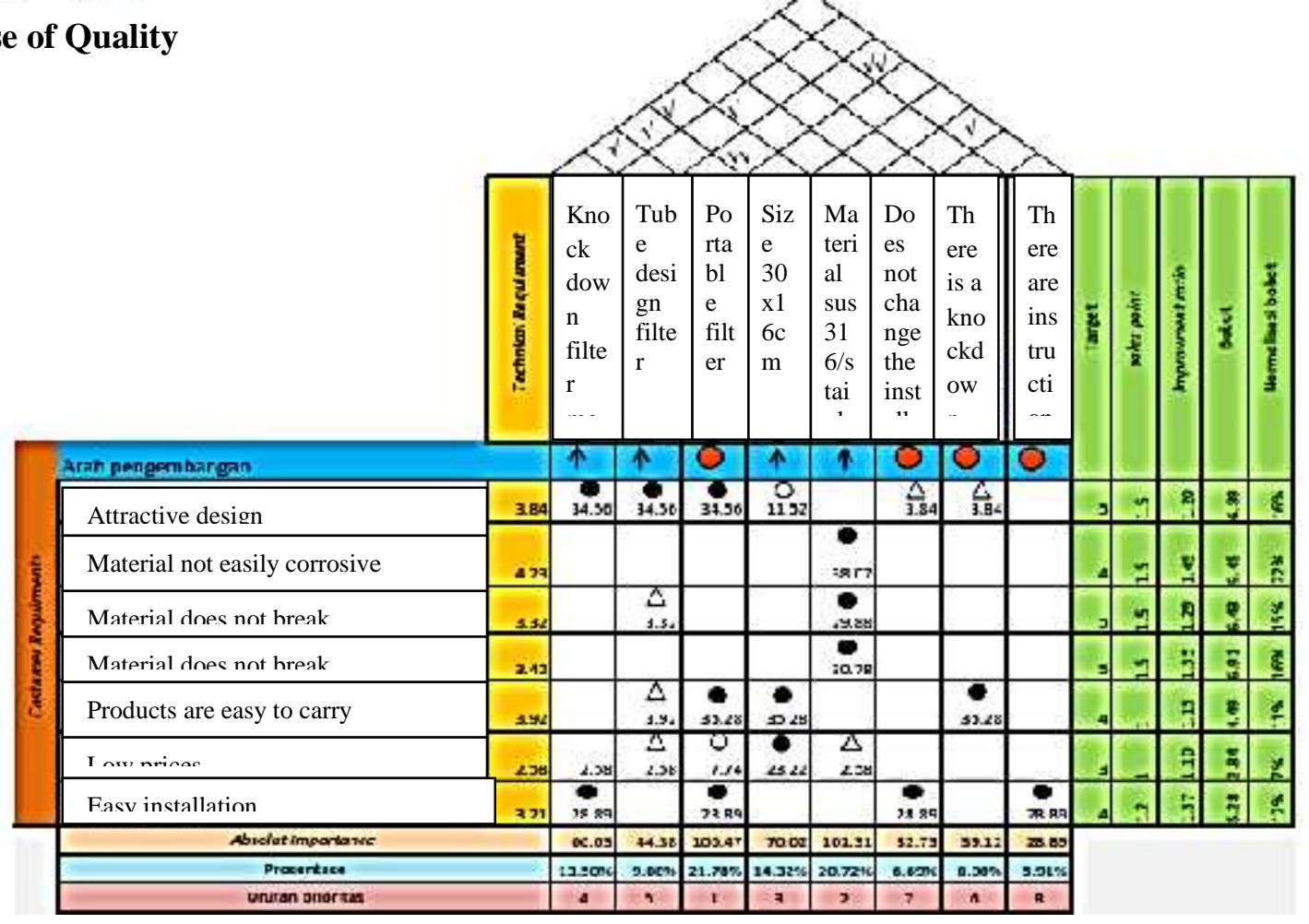

Figure 2. Ergonomic Knock DownHoQ Water Purifier 


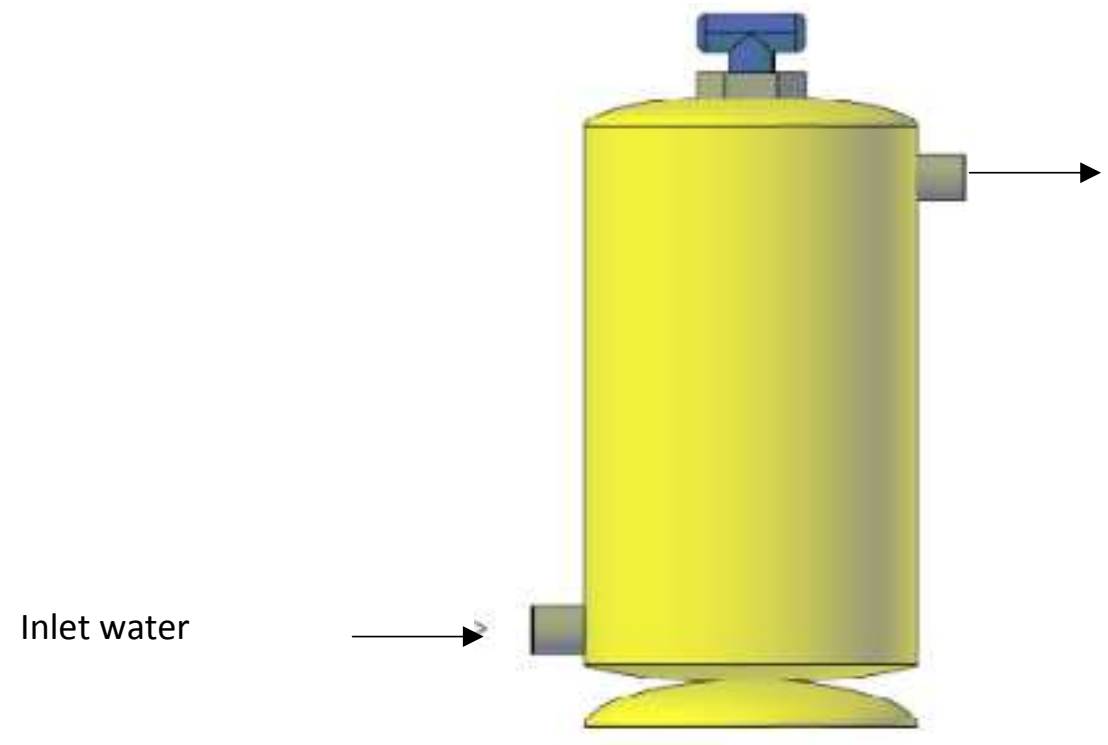

Figure 3. Ergonomic Knock Down Water Purifier Design

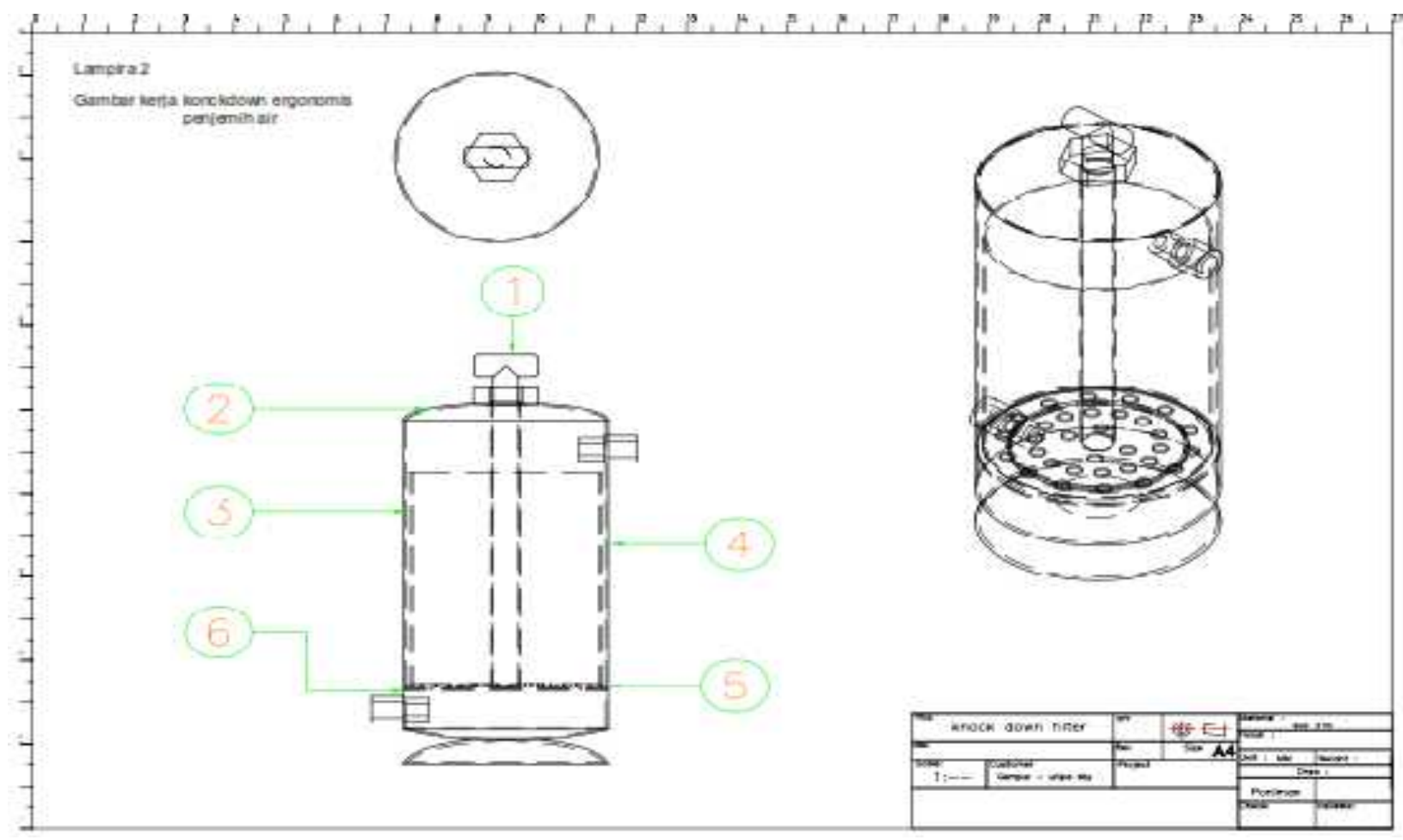

Information:

1. Stutbolt; 2. Top botton; 3. Filters; 3. Casing; 4. Seal / Packing; 5.ail pack

Figure: 4. Ergonomic Knockdown Design Layout for Water Purification 
Based on the analysis of planning above, it can be made in its implementation, see Figure 5 below.

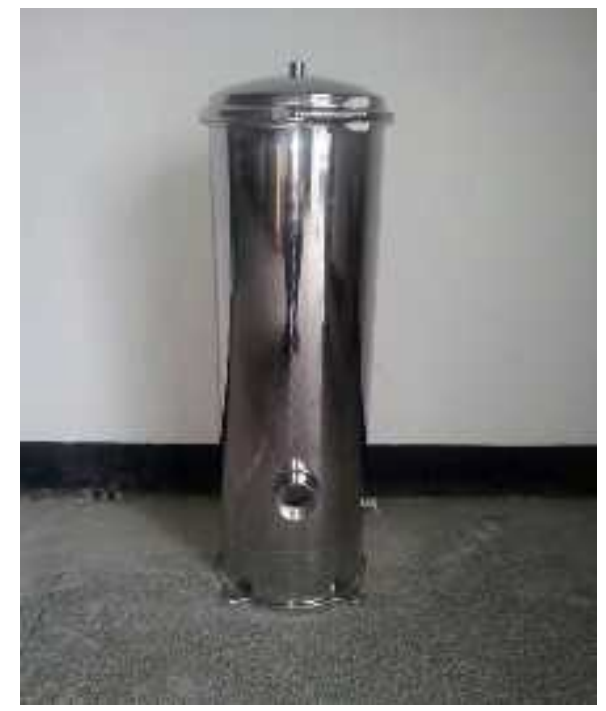

Figure 5. Shape of Ergonomic Knock Down Water Filter Implementation

\section{Ability (Capacity) to Filter Water}

Table 3. Average Results of Total Solid Disolves and Water Acidity in the Water Filter Experiment(June 2019)

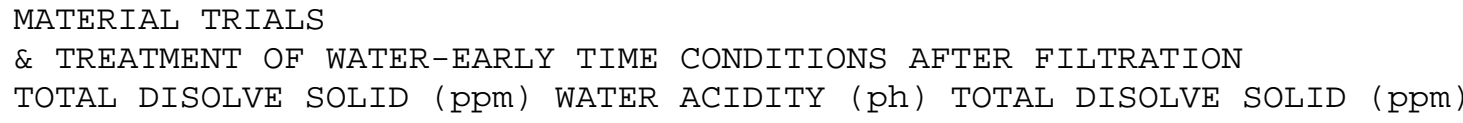

\begin{tabular}{|c|c|c|c|c|c|c|}
\hline \multirow[b]{2}{*}{ Trials } & \multirow[b]{2}{*}{$\begin{array}{c}\text { Material \& } \\
\text { Treatment }\end{array}$} & \multirow[b]{2}{*}{ Time } & \multicolumn{2}{|c|}{ Early Wate State } & \multicolumn{2}{|c|}{ Conditions After Filtration } \\
\hline & & & $\begin{array}{c}\text { Total } \\
\text { disolve } \\
\text { solid (ppm) }\end{array}$ & $\begin{array}{l}\text { Water acidity } \\
\text { (ph) }\end{array}$ & $\begin{array}{c}\text { Total } \\
\text { disolve } \\
\text { solid (ppm) }\end{array}$ & $\begin{array}{c}\text { Water } \\
\operatorname{acidity}(p h)\end{array}$ \\
\hline $\begin{array}{l}\text { Initial well } \\
\text { water } \\
\text { conditions }\end{array}$ & - & - & 380 & 7,4 & 380 & 7,4 \\
\hline TrialI & $\begin{array}{l}\text { Carbon, silica, ziolit, } \\
\text { ceramic, foam }\end{array}$ & & 380 & 7,4 & 378 & 7,1 \\
\hline Trial II & $\begin{array}{l}\text { Carbon, silica, ziolit, } \\
\text { ceramic, foam }\end{array}$ & $\begin{array}{c}\text { After } 1 \\
\text { weeks Trial } \\
1\end{array}$ & 378 & 7,1 & 345 & 6,8 \\
\hline Trial III & $\begin{array}{l}\text { Carbon, silica, ziolit, } \\
\text { ceramic, foam }\end{array}$ & $\begin{array}{c}\text { Elektrolisfo } \\
\text { r } 24 \\
\text { minutes }\end{array}$ & 345 & 6,8 & 330 & 6,8 \\
\hline Trial IV & $\begin{array}{c}\text { - Electrolysis(12V } 10 \\
\text { A) } \\
\text { Carbon, silica, ziolit, } \\
\text { ceramic, foam }\end{array}$ & $\begin{array}{l}\text { Elektrolisfo } \\
\text { r 54minutes }\end{array}$ & 330 & 6,8 & 296 & 6,9 \\
\hline TrialV & $\begin{array}{c}\text {-Electrolysis (12V } 10 \\
\text { A) } \\
\text { Carbon, silica, ziolit, } \\
\text { foam, ferrolite, } \\
\text { manganese and jade }\end{array}$ & - & 296 & 6,9 & 156 & 7,3 \\
\hline
\end{tabular}


Based on the experimental results of filter material (see table 3 above) ergonomic knock down water filter has the ability to reduce total dissolved solids (TDS) levels from $380 \mathrm{ppm}$ to 156 ppm, down 224 ppm (41\%). Experiment with changing ingredients and electrolysis. Filter materials that produce water filtration are: carbon, silica, ziolite, foam, ferrolite, manganese and jade.

\section{CONCLUSIONS AND SUGGESTIONS}

Conclusion: 1). Based on the House of Quality analysis results for the manufacture and implementation of ergonomic knock down water filters, there are seven attributes of the level of consumer needs, namely: a) Attractive design, b) Material is not easily corrosive / stainles still, c) Material is not easily broken, d) Resistant against rust, e) Product is easy to carry / simple, f) Low price, and g) Easy installation. 2). Ergonomic knock down water filter has the ability to reduce total dissolved solids (TDS) levels from $380 \mathrm{ppm}$ to $156 \mathrm{ppm}$, down 224 ppm (41\%) by electrolysis method with carbon, silica, ziolite, foam, ferrolite, manganese and rock filters. jade. Suggestion: For the implementation of Quality Function Deployment ergonomic knock down water filters are expected to be guided by Hoq analysis according to the conclusions above.

\section{REFERENCES}

1. Diane Ingle, 2014, Workplace effeciency improved with ergonomics, Occupational nurce educator public heath office, USA.

2. Effendi, H. 2003, Telaah kualitas air, Kanisius, Yogyakarta.

3. Gempur Santoso, 2004, Ergonomi Manusia, Peralatan Dan Lingkungan. Prestasi Pustaka Publisher, Jakarta.

4. Nicola, Effendra (2015) Hubungan Antara Konduktivitas, TDS (Total Dissolved Solid) Dan TSS (Total Suspended Solid) Dengan Kadar $\mathrm{Fe}^{2+}$ dan Fe Total Pada Air Sumur Gali. Skripsi Jurusan Kimia Fakultas Matematika Dan Ilmu Pengetahuan Alam Universitas Jember.

5. Peraturan pemerintah No.20 tahun 1990, tentang Pengendalian Pencemaran Air.

6. Rahayu, N.I. (2015), Model Rotasi Pekerjaan Berdasarkan faktor ergonomi, Thesis, Institut Teknologi Sepuluh Nopember Surabaya.

7. Utama water filter,2014-2018, Masalah Air Bersih di Indonesia Seperti Tidak Pernah Usai, Utama Filter,http://www.utamawaterfilter.co $\underline{\mathrm{m} /}$ 